\title{
PERSEPSI SISWA TERHADAP KETERAMPILAN GURU DALAM PEMBELAJARAN PENDIDIKAN JASMANI OLAHRAGA DAN KESEHATAN DI SDN 16 PISANG KECAMATAN PAUH KOTA PADANG
}

\author{
Syafruddin $^{1}$, Deswandi ${ }^{2}$, Nurul Ikhsan ${ }^{3}$ \\ ${ }^{1}$ Program Studi Pendidikan Jasmani Kesehatan dan Rekreasi, Fakultas Ilmu Keolahragaan, \\ Universitas Negeri Padang, Jalan Prof. DR. Hamka Air Tawar Barat, Padang, 25132, Indonesia \\ ${ }^{2}$ Program Studi Pendidikan Jasmani Kesehatan dan Rekreasi, Fakultas Ilmu Keolahragaan, \\ Universitas Negeri Padang, Jalan Prof. DR. Hamka Air Tawar Barat, Padang, 25132, Indonesia \\ ${ }^{3}$ Program Studi Pendidikan Jasmani Kesehatan dan Rekreasi, Fakultas Ilmu Keolahragaan, \\ Universitas Negeri Padang, Jalan Prof. DR. Hamka Air Tawar Barat, Padang, 25132, Indonesia
}

E-mail: Nurulikhsan@ fik.unp.ac.id ${ }^{1}, \underline{\text { syafruddin@ fik.unp.ac.id }}{ }^{2}, \underline{\text { deswandi@ } @ \text { fik.unp.ac.id }}^{3}$

\begin{abstract}
Abstrak
Dalam Pembelajaran Pendidikan Jasmani Olahraga Dan Kesehatan Di SDN 16 Pisang Kecamatan Pauh Kota Padang ditemui permasalahan yang timbul di lapangan dimana tidak efektifnya pembelajaran pendidikan jasmani olahraga dan kesehatan seperti keterampilan dalam membuka dan menutup pelajaran, menjelaskan pelajaran dan mengelola kelas. Hal ini menyebabkan kurangnya perhatian siswa terhadap pembelajaran yang dilakukan oleh guru pendidikan jasmani seperti: siswa merasa bosan atau tidak sesuai dengan pola mengajar yang diterapkan guru, siswa memandang guru kurang menguasai bahan pelajaran yang sedang disajikan.

Penelitian ini merupakan jenis penelitian deskriptif yang bertujuan untuk mengetahui sejauhmana Persepsi Siswa Terhadap Keterampilan Guru Dalam Pembelajaran Pendidikan Jasmani Olahraga Dan Kesehatan Di SDN 16 Pisang Kecamatan Pauh Kota Padang. Populasi pada penelitian ini adalah Siswa-Siswi SDN 16 Pisang Kecamatan Pauh Kota Padang Tahun Ajaran 2012/2013 yang terdiri dari siswa kelas IV sebanyak 235 orang yang terdiri dari 98 siswa dan 135 siswi, kelas V sebanyak 204 orang yang terdiri dari 84 siswa dan 120 siswi serta kelas VI sebanyak 200 orang yang terdiri dari 84 siswa dan 116 siswi. Total populasi keseluruhan adalah sebanyak 639 orang. Sampel dalam penelitian ini diambil $10 \%$ dari siswa-siswi kelas IV dan kelas V dengan menggunakan teknik Strata Stratified Purposive Random sampling yaitu siswa kelas IV sebanyak 24 orang yang terdiri dari 10 laki-laki dan 14 perempuan, kelas V sebanyak 20 orang yang terdiri dari 8 laki-laki dan 12 perempuan. Total keseluruhan 44 orang. Alat pengumpul data dilakukan dengan angket berskala Likert, sedangkan teknik analisis data menggunakan analisis deskriptif melalui tabulasi frekuensi.

Hasil analisis data terhadap masing-masing variabel ditemukan : (1) Persepsi siswa terhadap guru dalam membuka pembelajaran diklasifikasikan "Cukup" dengan perolehan persentase $(54,54 \%)$. (2) Persepsi siswa terhadap guru dalam materi pembelajaran diklasifikasikan "Cukup" yaitu dengan perolehan persentase (58,40\%). (3) Persepsi siswa terhadap guru dalam metode pembelajaran diklasifikasikan "Cukup" yaitu dengan perolehan persentase $(52,98 \%)$. (4) Persepsi siswa terhadap guru dalam menutup pembelajaran diklasifikasikan "Cukup" dengan perolehan persentase (52,27\%).
\end{abstract}

Kata Kunci: Persepsi Siswa, Keterampilan Guru dan Pembelajaran Penjasorkes 


\section{PENDAHULUAN}

Pada Undang-undang RI No. 20 tahun 2003 BAB II pasal 3 tentang Sistem Pendidikan Nasional (2008:5), dijelaskan bahwa pendidikan nasional berfungsi mengembangkan kemampuan dan membentuk watak serta peradaban bangsa yang bermartabat dalam rangka mencerdaskan kehidupan bangsa, bertujuan untuk berkembangnya potensi peserta didik agar menjadi manusia yang beriman dan bertakwa kepada Tuhan Yang Maha Esa, berakhlak mulia, sehat, berilmu, cakap, kreatif, mandiri, dan menjadi warga negara yang demokratis serta bertanggung jawab.

Agar dapat mewujudkan hal tersebut, maka diselenggarakan pendidikan secara berjenjang mulai pendidikan dasar, menengah, sampai pendidikan tinggi. Pendidikan adalah usaha sadar dan terencana untuk mewujudkan suasana belajar dan proses pembelajaran agar peserta didik secara aktif mengembangkan potensi dirinya untuk memiliki kekuatan spiritual keagamaan, pengendalian diri, kepribadian, kecerdasan, akhlak mulia, serta keterampilan yang diperlukan dirinya, masyarakat bangsa dan Negara.

Kegiatan pembelajaran harus dikelola dengan baik, efektif dan profesional agar dapat mencapai sasaran yang diinginkan. Pengelolaan pembelajaran yang baik dan terencana, juga dimaksudkan agar peserta didik (siswa) dapat mencapai hasil belajar yang maksimal.

Sebagai

suatu sistem,

pembelajaran pendidikan jasmani olahraga dan kesehatan akan dipengaruhi oleh berbagai komponen yang membentuknya. Menurut Sanjaya (2008:25) pembelajaran pendidikan jasmani olahraga dan kesehatan siswa di sekolah dipengaruhi oleh banyak faktor, diantaranya; Keterampilan guru pendidikan jasmani olahraga dan kesehatan, siswa, sarana dan prasarana serta faktor lingkungan.

Guru pendidikan jasmani olahraga dan kesehatan merupakan orang yang secara langsung berhadapan dengan siswa. Pada sistem pembelajaran guru bisa berperan sebagai perencana (planer) atau desainer (designer) pembelajaran pendidikan jasmani olahraga dan kesehatan, sebagai implementator atau mungkin keduanya.

Sebagai perencana guru pendidikan jasmani olahraga dan kesehatan dituntut untuk memahami secara benar kurikulum yang berlaku, karakteristik siswa, fasilitas dan sumber daya yang ada, sehingga semuanya dijadikan komponen-komponen dalam menyusun rencana dan desain pembelajaran pendidikan jasmani olahraga dan kesehatan.

Dalam pelaksanaan perannya sebagai implementator rencana dan desain pembelajaran guru pendidikan jasmani olahraga dan kesehatan bukanlah hanya berperan sebagai model atau teladan bagi siswa yang diajarnya akan tetapi juga sebagai pengelola pembelajaran (manager of learning) dan memiliki keterampilan yang baik dalam proses pembelajaran .

Keterampilan yang baik dalam proses pembelajaran guru pendidikan jasmani olahraga dan kesehatan akan terlihat dari keterampilan seorang guru dalam membuka dan menutup pelajaran, menjelaskan pelajaran dan mengelola kelas dengan baik agar terciptanya suasana pembelajaran yang kondusif.

Dengan demikian efektifitas proses pembelajaran pendidikan 
jasmani olahraga dan kesehatan terletak dipundak guru. Guru yang tidak mampu bertindak sebagai perencana yang baik tidak akan dapat melaksanakan perannya sebagai pengelola pembelajaran pendidikan jasmani olahraga dan kesehatan dengan baik. Hal ini tentunya akan mempengaruhi hasil belajar siswa.

Selanjutnya siswa merupakan organisme yang unik yang berkembang sesuai dengan tahap perkembangannya. Perkembangan siswa adalah perkembangan seluruh aspek kepribadiannya, akan tetapi tempo dan irama perkembangan masing-masing siswa pada setiap aspek tidak selalu sama.

Proses pembelajaran pendidikan jasmani olahraga dan kesehatan dapat dipengaruhi oleh perkembangan siswa yang tidak sama itu, di samping karakteristik lain yang melekat pada diri siswa, seperti; aspek latar belakang meliputi jenis kelamin siswa, tempat kelahiran dan tempat tinggal siswa, tingkat sosial ekonomi siswa, dari keluarga mana siswa berasal dan lain sebagainya.

Sedangkan dilihat dari sifat yang dimiliki siswa meliputi kemampuan dasar, pengetahuan dan sikap. Semua itu akan mempengaruhi proses pembelajaran pendidikan jasmani olahraga dan kesehatan di dalam kelas ataupun di lapangan olahraga.

Sarana adalah segala sesuatu yang mendukung secara langsung terhadap kelancaran proses pembelajaran pendidikan jasmani olahraga dan kesehatan, seperti; media pembelajaran, alat-alat pelajaran (alatalat olahraga), perlengkapan sekolah dan lain sebagainya.

Prasarana adalah segala sesuatu yang secara tidak langsung dapat mendukung keberhasilan proses pembelajaran pendidikan jasmani olahraga dan kesehatan, seperti; lapangan olahraga dan sebagainya. Kelengkapan sarana dan prasarana akan membantu guru dalam proses pembelajaran pendidikan jasmani olahraga dan kesehatan.

Apabila sarana dan prasarana yang dimiliki kurang lengkap, akan dapat mempengaruhi efektifitas pembelajaran pendidikan jasmani olahraga dan kesehatan. Guru akan kesulitan untuk mengatur kegiatan belajar siswa dan terjadinya ketidak efisiennya waktu yang tersedia.

Faktor lingkungan merupakan dimensi lingkungan yang ada dan mempengaruhi proses pembelajaran pendidikan jasmani olahraga dan kesehatan, seperti; organisasi kelas dan iklim sosial-psikologis.

Organisasi kelas meliputi jumlah siswa dalam satu kelas merupakan aspek penting yang dapat mempengaruhi proses pembelajaran. Organisasi kelas yang terlalu besar akan kurang efektif untuk mencapai tujuan pembelajaran.

Hal ini dapat menyebabkan kurang menguntungkan dalam menciptakan iklim belajar mengajar yang baik. Selanjutnya iklim sosialpsikologis maksudnya adalah keharmonisan hubungan antara orang yang terlibat dalam proses pembelajaran, baik antara sesama siswa, guru dengan guru dan guru dengan pimpinan sekolah serta pihak sekolah dengan lembaga masyarakat.

Sekolah yang memiliki hubungan yang baik ditunjukkan oleh adanya kerjasama yang baik secara internal, maka memungkinkan iklim belajar menjadi sejuk dan tenang sehingga 
akan berdampak pada motivasi belajar siswa.

Sebaliknya, manakala hubungan tidak harmonis, maka iklim belajar akan penuh dengan ketegangan dan ketidaknyamanan sehingga akan mempengaruhi psikologis siswa dalam belajar.

Demikian juga sekolah yang memiliki hubungan yang baik dengan lembaga-lembaga luar akan menambah kelancaran program-program sekolah sehingga upaya-upaya sekolah dalam meningkatkan kualitas pembelajaran akan mendapat dukungan dari pihak lain.

Dari beberapa uraian di atas, faktor guru merupakan faktor yang dianggap penting dan diduga mempengaruhi pembelajaran pendidikan jasmani olahraga dan kesehatan.

Siswa akan berhasil dalam mencapai prestasi yang maksimal apabila guru memiliki keterampilan yang baik dalam membuka dan menutup pelajaran, mampu menjelaskan pelajaran dan mampu mengelola kelas dengan baik, artinya pembelajaran pendidikan jasmani olahraga dan kesehatan dapat terlaksana dengan baik.

Persoalan yang muncul khususnya di dalam pembelajaran pendidikan jasmani olahraga dan kesehatan adalah bagaimana membuat agar seorang guru harus mampu mengelola interaksi antara guru dan siswa dalam pembelajaran.

Kemudian seorang guru harus mampu memahami hakekat belajar, faktor-faktor yang mempengaruhi aktivitas belajar, bagaimana proses belajar berlangsung dan ciri-ciri belajar dalam berbagai bidang, yakni pengetahuan, pemahaman, perasaan, minat, sikap, nilai dan keterampilan.

Dengan demikian guru akan mampu menentukan jenis gaya memimpin kelas yang akan dipakai. Hal ini akan mempengaruhi corak interaksi guru dan siswa dalam pembelajaran.

Berdasarkan uraian-uraian di atas, sangat diperlukan kompetensi seorang guru terhadap pembelajaran pendidikan jasmani olahraga dan kesehatan di sekolah, meliputi keterampilan yang baik dalam membuka dan menutup pelajaran, mampu menjelaskan pelajaran dan mampu mengelola kelas dengan baik.

Proses pembelajaran pendidikan jasmani olahraga dan kesehatan merupakan aspek penting yang perlu diperhatikan adanya interaksi dua arah antara siswa dengan guru. Siswa sebagai warga belajar, dan guru sebagai sumber belajar.

Dalam hal ini guru tidak hanya bertugas sebagai pengajar, akan tetapi juga mendidik. Artinya, guru harus mampu mentransfer nilai-nilai yang dimiliki kepada siswanya. Nilai-nilai tersebut harus dapat diwujudkan dalam bentuk tingkah laku sehari-hari.

Oleh sebab itu sangat dibutuhkan proses pembelajaran yang baik dari seorang guru pendidikan jasmani olahraga dan kesehatan yaitu memberikan kesempatan kepada peserta didik untuk terlibat langsung dalam berbagai pengalaman belajar melalui aktivitas jasmani, olahraga dan kesehatan yang terpilih yang dilakukan secara sistematis.

Dalam pembelajaran pendidikan jasmani olahraga dan kesehatan di dalam kelas maupun di lapangan tidak lepas dari keterampilan dasar mengajar seperti yang dikemukakan di atas. 
Terlaksananya interaksi belajar mengajar antara guru dan siswa di tentukan oleh seberapa besar seorang guru menguasai keterampilan dasar mengajar yang dimiliki oleh seorang guru serta dilaksanakan dengan baik.

Maka akan memudahkan guru tersebut mengelola pengajaran itu sendiri hasil yang diperoleh akan sesuai dengan apa yang diinginkan.Keterampilan dasar yang dimiliki guru pendidikan jasmani olahraga dan kesehatan, seharusnya menimbulkan motivasi siswa untuk mengikuti untuk mengikuti pelajaran penjasorkes dengan semangat, senang dan gembira sehingga pembelajaran penjasorkes dengan baik.

Berdasarkan fenomena di lapangan dan wawancara dengan kepala sekolah di SDN 16 Pisang Kecamatan Pauh Kota Padang, penulis menduga permasalahan yang timbul di lapangan sekarang adalah tidak efektifnya pembelajaran pendidikan jasmani olahraga dan kesehatan seperti keterampilan dalam membuka dan menutup pelajaran, menjelaskan pelajaran dan mengelola kelas.

Hal ini menyebabkan kurangnya perhatian siswa terhadap pembelajaran yang dilakukan oleh guru pendidikan jasmani seperti: siswa merasa bosan atau tidak sesuai dengan pola mengajar yang diterapkan guru, siswa memandang guru kurang menguasai bahan pelajaran yang sedang disajikan.

Kemudian tidak efektifnya pengelolaan kelas yang dilakukan oleh guru pendidikan jasmani olahraga dan kesehatan seperti : masih ditemukannya siswa melakukan gerakan-gerakan fisik yang bersifat mengganggu terhadap siswa lain.

Jika dibiarkan perilaku-perilaku tersebut, maka akan menimbulkan suasana yang tidak menyenangkan dalam pembelajaran pendidikan jasmani olahraga dan kesehatan. Selanjutnya akan berdampak terhadap hasil belajar yang diharapkan akan sulit untuk diraih.

Siswa merupakan lingkungan terdekat guru pendidikan jasmani olahraga dan kesehatan di sekolah yang memiliki berbagai persepsi tentang bagaimana pembelajaran pendidikan jasmani olahraga dan kesehatan di sekolah.

Untuk itu perlu adanya penelitian secara ilmiah untuk mengetahui pembelajaran pendidikan jasmani olahraga dan kesehatan di SDN 16 Pisang Kecamatan Pauh Kota Padang, Sehingga dari hasil penelitian ini bisa dilahirkan suatu kesimpulan yang bisa dijadikan langkah antisipatif bagi peningkatan hasil belajar siswa ke depan.

DEPDIKNAS dalam Kamus Besar Bahasa Indonesia (2008: 1061), "Persepsi adalah tanggapan (penerimaan) langsung dari sesuatu". maksudnya persepsi adalah penerimaan langsung dari seseorang terhadap suatu informasi dari objek yang dilihat dan di dengar.

Persepsi menurut Slameto (2003:102) adalah "proses yang menyangkut masuknya pesan atau informasi ke dalam otak manusia. Melalui persepsi manusia terusmenerus mengadakan hubungan dengan lingkungannya. Hubungan ini dilakukan lewat inderanya, yaitu indera penglihat, pendengar, peraba, perasa, dan pencium". Melalui persepsi individu dapat menyadari, dapat mengerti tentang keadaan lingkungan yang ada disekitarnya, dan juga tentang keadaan diri individu yang bersangkutan. 
Persepsi merupakan suatu proses yang didahului oleh penginderaan, penginderaan merupakan suatu proses diterimanya stimulus oleh individu melalui alat penerima yaitu indera.

Kemudian stimulus tersebut diteruskan oleh syaraf ke otak sebagai pusat susunan syaraf. Stimulus yang diterima individu itu kemudian diorganisasikan, diinterpretasikan sehingga individu menyadari tentang apa yang di inderanya itu.

Persepsi seseorang terhadap dirinya sendiri sangat mempengaruhi pembentukan kesan Atas kepada orang lain. Persepsi sangat mempengaruhi pembentukan kesan Atas kepada orang lain atau orang asing yang ditemuinya.

Dalam proses belajar mengajar agar tercapai guru hendaknya perlu mengetahui karakteristik kognitif siswa, karena karakter kognitif siswa dapat dipengaruhi oleh persepsi siswasiswanya. Agar tidak terjadi hal tersebut.

Berdasarkan pendapat para ahli di atas dapat disimpulkan bahwa pembelajaran adalah suatu proses interaksi antara peserta didik dengan lingkungannya, sehingga terjadi perubahan perilaku ke arah yang lebih baik, atau dengan kata lain pembelajaran adalah interaksi langsung antara guru dengan siswa berkaitan dengan pengelolaan proses belajarmengajar. .

Kemudian tujuan pembelajaran adalah untuk menilai pembelajaran, membimbing siswa belajar, merancang sistem pembelajaran, melakukan komunikasi dengan guru-guru lainnya dalam meningkatkan proses pembelajaran, dan melakukan kontrol terhadap ketercapaian pelaksanaan pembelajaran.
Tamat dan Mirman (1999:5) mengemukakan bahwa "Pendidikan jasmani olahraga dan kesehatan merupakan usaha untuk mempengaruhi pertumbuhan dan perkembangan anak ke arah kehidupan yang sehat jasmani dan rohani." Usaha tersebut berupa kegiatan jasmani atau fisik yang diprogram kan secara ilmiah, terarah, dan sismatis, yang disusun oleh lembaga pendidikan yang kompeten.

International Charter of Physical

Education and Sport dari UNESCO (dalam Lutan, 2001:5) disebutkan bahwa "Pendidikan jasmani olahraga dan kesehatan adalah suatu proses pendidikan seseorang baik sebagai perorangan maupun sebagai anggota masyarakat yang dilakukan secara sadar dan sistematis, melalui berbagai kegiatan dalam rangka memperoleh peningkatan kemampuan dan keterampilan jasmani, pertumbuhan, kecerdasan, dan membentuk watak.

Hal tersebut menunjukkan betapa eratnya hubungan antara jasmani dan rohani dalam kegiatan pendidikan jasmani olahraga dan kesehatan. Lutan (2001:5) mengatakan bahwa "Pendidikan jasmani olahraga dan kesehatan adalah proses pendidikan melalui aktivitas jasmani, permainan dan/atau olahraga." Jadi, yang digunakan medium atau perantara disini adalah serangkaian aktivitas jasmani, permainan atau mungkin juga cabang olahraga. Melalui serangkaian kegiatan inilah seorang siswa, dibina dan sekaligus dibentuk. Dikatakan dibina, karena yang ditumbuhkembangkan adalah potensinya. Dikatakan pembentukan, karena memang akan terjadi proses pembiasaan melalui seperangkat stimulus.

Berdasarkan pendapat ahli di atas dapat disimpulkan bahwa pendidikan 
jasmani olahraga dan kesehatan merupakan proses pendidikan keseluruhan yang memanfaatkan aktifitas jasmani dengan melibatkan otot-otot besar melalui mekanisme gerak tubuh manusia. Aktifitas ini direncanakan secara sistematis bertujuan untuk mengembangkan dan meningkatkan kesegaran jasmani, perkembangan keterampilan motorik, pengetahuan dan prilaku yang baik dan dengan mengembangkan sikap sportif.

Dari beberapa pengertian mengenai pembelajaran, dan pendidikan jasmani olahraga dan kesehatan maka proses pembelajaran dalam pendidikan jasmani olahraga dan kesehatan bisa diartikan sebagai suatu kegiatan siswa untuk menerima, dan menanggapi pelajaran pendidikan jasmani olahraga dan kesehatan yang diberikan oleh guru pendidikan jasmani olahraga dan kesehatan.

Pembelajaran pendidikan jasmani olahraga dan kesehatan merupakan usaha sadar dan terencana untuk mewujudkan suasana belajar dan proses pembelajaran agar peserta didik secara aktif mengembangkan potensi kemampuan tubuh seseorang untuk melaksanakan tugas dalam kehidupan sehari-hari tanpa mengalami kelemahan yang berarti dan masih memiliki cadangan tenaga untuk menghadapi keadaan darurat yang datang tiba-tiba.

Berdasarkan uraian di atas dapat disimpulkan bahwa pembelajaran pendidikan jasmani olahraga dan kesehatan merupakan usaha sadar dan terencana untuk mewujudkan perkembangan anak secara menyeluruh melalui aktivitas jasmani melalui proses pembelajaran penjasorkes peserta didik secara aktif mengembangkan potensi kemampuan tubuhnya untuk melaksanakan tugas dalam kehidupan sehari-hari tanpa mengalami kelelahan yang berarti, dan masih memiliki cadangan tenaga untuk menghadapi keadaan darurat yang datang tiba-tiba. Perkembangan ini mencakup organik, neuromuskuler, intelektual dan emosional.

\section{a. Tujuan Pendidikan jasmani olahraga dan kesehatan}

Alimunar (2004: 4) tujuan pendidikan jasmani olahraga dan kesehatan adalah sebagai berikut:

1) Kesegaran jasmani

2) Pertumbuhan dan perkembangan anak secara optimal.

3) Pengembangan intelektual.

4) Pembentukan kerjasama sosial

Pengalaman yang diperoleh seseorang dengan orang lain dalam pendidikan jasmani olahraga dan kesehatan dan olahraga merupakan motivasi untuk terus melakukan kegiatan olahraga. Persaingan sehat merupakan hal yang berharga kalau diambil diantara sesama, yang kemudian menjadi kegembiraan dan pengalaman bersama. Persoalanya terletak bagaimana dapat dicapai peningkatan kerjasama dan persaingan sehat dalam pendidikan jasmani olahraga dan kesehatan.

Melalui kerjasama dan persaingan sehat dapat ditanamkan kemampuan sosial. Pada hakekatnya mereka dapat memberikan kepuasan, saling mendapatkan pengalaman, menimbulkan motivasi dalam kegembiraan yang positif. Persaingan yang sehat dalam pendidikan jasmani olahraga dan kesehatan akan dapat meningkatkan hubungan persahabatan yang baik.

Dari penjelasan di atas dapat diambil kesimpulan bahwa tujuan pendidikan jasmani olahraga dan 
kesehatan bukan hanya kegiatan olahraga semata yang dianggap oleh masyarakat umum bahwa kegiatan ini hanya melibatkan otot-otot semata. Tetapi setelah dijelaskan di atas, jelas sekali bahwa pendidikan jasmani olahraga dan kesehatan bukan hanya kegiatan olahraga semata tetapi melibatkan beberapa aspek penting seperti kekuatan intelektual, kontrol emosi, kekuatan otot dan kontrol neuro muskuler.

Kesalahan yang sering terjadi selama proses pembelajaran berlangsung guru hanya menggunakan pola interaksi satu arah, yaitu dari guru ke siswa. Pola interaksi yang demikian bukan dapat membuat iklim pembelajaran menjadi statis, tetapi dapat memasung kreatiftas siswa. Oleh sebab itu, guru perlu menggunakan variasi interaksi dua arah, yaitu pola interaksi siswa - guru - siswa, bahkan pola interaksi yang multi arah.

Pembelajaran pendidikan jasmani olahraga dan kesehatan merupakan serangkaian kegiatan guru dan siswa atas dasar hubungan timbal balik (interaksi), dimana peristiwa in berlangsung dalam situasi edukatif untuk mencapai tujuan pendidikan jasmani olahraga dan kesehatan.

\section{METODE}

Sudjana (1989: 64) menyatakan "Penelitian Deskriptif merupakan Penelitian yang berusaha mendeskripsikan gejala, peristiwa, kejadian yang terjadi pada saat sekarang. Penelitian Deskriptif mengambil masalah atau memusatkan perhatian kepada masalah-masalah aktual sebagaimana adanya pada saat Penelitian dilaksanakan".

Merujuk dari pendapat di atas dan berdasarkan permasalahan yang akan dibahas dalam penelitian ini, maka Penelitian ini digolongkan dalam jenis penelitian deskriptif. Penelitian ini bertujuan untuk menggambarkan dan menafsirkan tentang Persepsi Siswa Terhadap Keterampilan Guru dalam Pembelajaran Pendidikan jasmani olahraga dan kesehatan di SDN 16 Pisang Kecamatan Pauh Kota Padang.

Penelitian dilaksanakan pada bulan April 2014. Penelitian ini bertempat di SDN 16 Pisang Kecamatan Pauh Kota Padang.

\section{Populasi dan Sampel \\ 1. Populasi}

Populasi adalah seluruh data atau objek, individu, peristiwa yang menjadi perhatian penelitian dalam suatu ruang lingkup dan waktu kita tentukan. Secara rinci oleh Arikunto (2002:108), menyatakan bahwa "populasi adalah keseluruhan objek penelitian yang terdiri dari manusia, benda- benda, hewan, tumbuhtumbuhan, gejala-gejala, nilai test atau peristiwa-peristiwa sebagai sumber data yang memiliki karakteristik tertentu di dalam suatu penelitian".

Dalam penelitian ini yang akan menjadi populasi adalah Siswa-Siswi SDN 16 Pisang Kecamatan Pauh Kota Padang Tahun Ajaran 2010/2011 yang terdiri dari siswa kelas IV sebanyak 235 orang yang terdiri dari 98 siswa dan 135 siswi, kelas V sebanyak 204 orang yang terdiri dari 84 siswa dan 120 siswi serta kelas VI sebanyak 200 orang yang terdiri dari 84 siswa dan 116 siswi. Total populasi keseluruhan adalah sebanyak 639 orang. Agar lebih jelasnya dapat dilihat pada tabel berikut:

\section{Tabel 1:}

Distribusi Populasi Penelitian SDN 16 Pisang Kecamatan Pauh Kota Padang 


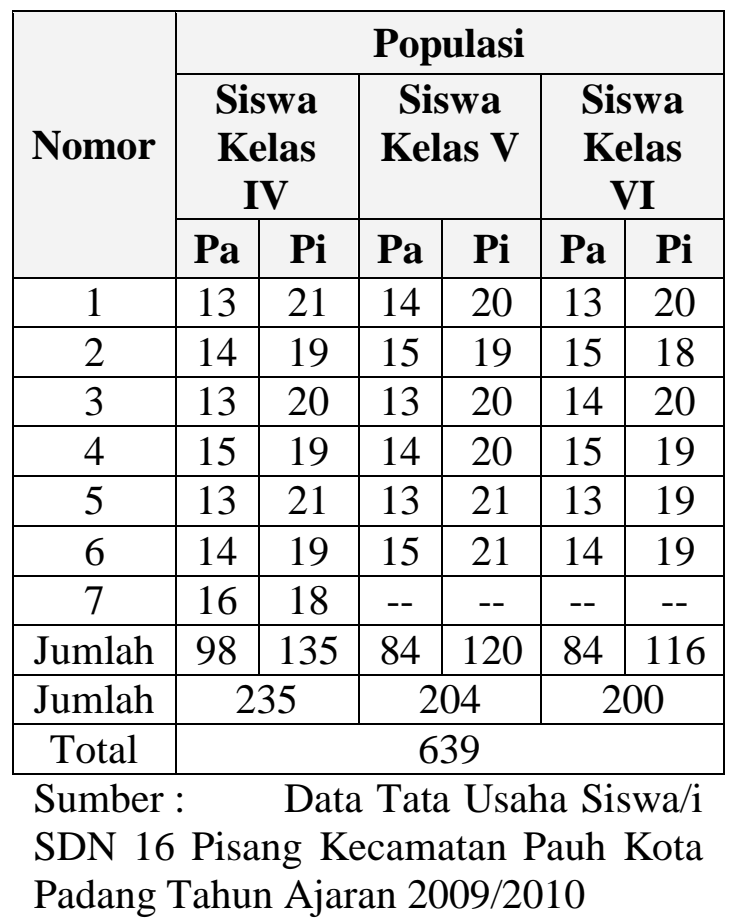

\section{Sampel}

Sampel penelitian adalah bagian dari populasi yang diambil dengan menggunakan cara-cara tertentu, sehubungan dengan pengambilan sampel ini maka Arikunto (2002:109) mengemukakan bahwa "suatu persoalan penting yang dihadapi seorang peneliti jika hendak mengadakan research sampling adalah, bagaimana dia dapat memperoleh sampel yang mewakili populasi."

Seperti diketahui bahwa sampel penelitian merupakan sebagian dari populasi atas keseluruhan populasi penelitian. Menurut Arikunto (2002:110) Mengemukakan "Jika penelitian mempunyai beberapa ratus subjek dalam populasi, mereka dapat menentukan sampel kurang lebih 10$15 \%$ atau 20-25\% atau lebih dari jumlah populasinya".

Dari pendapat diatas maka sampel dalam penelitian ini diambil $10 \%$ dari siswa-siswi kelas IV dan V, sedangkan kelas VI tidak diambil karena mengikuti Ujian Akhir Nasional. Sampel diambil dengan menggunakan teknik Strata Stratified Purposive Random sampling, maka dengan demikian diperoleh sebanyak 44 orang untuk dijadikan sampel. Agar lebih jelasnya tentang jumlah sampel yang akan digunakan dapat dilihat pada tabel berikut yang menerangkan persentase dari seluruh jumlah kelas IV dan $\mathrm{V}$ yang dijadikan sampel.

\section{Tabel 2:}

Distribusi Sampel Penelitian SDN 16 Pisang Kecamatan Pauh Kota Padang.

\begin{tabular}{|c|c|c|c|c|}
\hline & \multicolumn{4}{|c|}{ Sampel } \\
\hline & \multicolumn{2}{|c|}{$\begin{array}{c}\text { Siswa Kelas } \\
\text { IV }\end{array}$} & \multicolumn{2}{|c|}{$\begin{array}{c}\text { Siswa Kelas } \\
\text { V }\end{array}$} \\
\hline & $\mathbf{P a}$ & $\mathbf{P i}$ & $\mathbf{P a}$ & $\mathbf{P i}$ \\
\hline Jumlah & 10 & 14 & 8 & 12 \\
\hline Jumlah & \multicolumn{2}{|c|}{24} & \multicolumn{2}{|c|}{20} \\
\hline Total & \multicolumn{4}{|c|}{44 orang } \\
\hline
\end{tabular}

Berdasarkan tabel dua dapat dikemukakan bahwa yang terpilih sebagai sampel dalam penelitian ini adalah siswa kelas IV sebanyak 24 orang yang terdiri dari 10 siswa dan 14 siswi, kelas V sebanyak 20 orang yang terdiri dari 8 siswa dan 12 siswi. Total sampel keseluruhan adalah sebanyak 44 orang.

\section{Jenis dan Sumber Data}

\section{Jenis data}

Sesuai dengan tujuan penelitian yang akan dicapai maka jenis data yang diperlukan dalam penelitian ini adalah data primer dan data sekunder. Data primer yang dimaksud adalah data yang langsung diperoleh oleh peneliti dari responden, berupa informasi yang diberikan dalam menjawab pertanyaan yang berbentuk angket penelitian dan observasi.

Dalam hal ini data yang dimaksud adalah "Persepsi Siswa Terhadap 
Keterampilan

Guru

Pendidikan olahraga dan kesehatan di SDN 16 Pisang Kecamatan Pauh Kota Padang”. Kemudian, data sekunder yaitu data yang berasal dari arsip tentang data siswa yang diperoleh dari tata usaha SDN 16 Pisang Kecamatan Pauh Kota Padang.

\section{Sumber Data}

Adapun yang menjadi sumber data dalam penelitian adalah siswa SDN 16 Pisang Kecamatan Pauh Kota Padang. yang terpilih sebagai sampel.

\section{Teknik dan Alat Pengumpulan Data}

Agar memperoleh data yang diinginkan, maka Penulis menggunakan alat pengumpulan data adalah Angket atau Kuesioner, wawancara terbatas dan observasi langsung ke lapangan yang bertujuan untuk ricek. Angket merupakan daftar pertanyaan yang akan dijawab oleh responden, sedangkan wawancara dilakukan secara terbatas dengan siswa dan observasi dilakukan di lingkungan SDN 16 Pisang Kecamatan Pauh Kota Padang.

Dalam penyusunan angket terdapat juga pertanyaan yang mengarah pada pertanyaan positif dan negatif. Penulis menyusun angket penelitian yang diarahkan oleh dosen pembimbing. Kemudian menyebarkan angket kepada responden untuk memperoleh data Persepsi Siswa Terhadap Keterampilan Guru dalam Pembelajaran Pendidikan jasmani olahraga dan kesehatan di SDN 16 Pisang Kecamatan Pauh Kota Padang.

Penyusunan Angket dilakukan berdasarkan Skala Likert dengan empat (4) kategori jawaban adalah sebagai berikut : Selalu (S), Sering (SR), Jarang (JR), Tidak Ada (TA). Jawaban dari angket berupa data kualitatif yang kemudian diubah menjadi bentuk data kuantitatif dalam bentuk pertanyaan atau pernyataan positif $(+)$ adalah Selalu $(S)=$ 4 , Sering $(\mathrm{SR})=3$, Tidak Jarang $(\mathrm{JR})=$ 2 dan Tidak Ada (TA) $=1$. Sedangkan pertanyaan atau pernyataan negatif (-) adalah : Selalu $(S)=1$, Sering $(S R)=2$, Jarang $(\mathrm{JR})=3$ dan Tidak Ada $(\mathrm{TA})=4$.

Setelah pengolahan data nantinya, angka tersebut diubah lagi menjadi data kualitatif untuk memudahkan dalam pembahasan dimana untuk pertanyaan atau pernyataan bernilai positif (+) adalah : Selalu $(S)=4$, Sering $(S R)=3$, Tidak Jarang $(\mathrm{JR})=2$ dan Tidak Ada $(\mathrm{TA})=$ 1. Sedangkan pertanyaan atau pernyataan negatif (-) adalah : Selalu $(S)=1$, Sering $(S R)=2$, Jarang $(J R)=$ 3 dan Tidak Ada $(\mathrm{TA})=4$.

Angket disusun berdasarkan beberapa langkah-langkah adalah sebagai berikut :

1. Membuat kisi-kisi.

2. Menetapkan indikator-indikator dari setiap variabel yang akan diteliti.

3. Merumuskan pernyataan (item) dari setiap indikator.

4. Mengkonsultasikan pernyataan tersebut kepada Dosen Pembimbing.

\section{Teknik Analisis Data}

Setelah semua data berhasil dikumpulkan kemudian diolah, karena jenis penelitian ini bersifat deskriptif maka teknik analisis yang dapat digunakan adalah dengan menggunakan teknik distribusi frekwensi (statistik deskriptif) dengan perhitungan persentase, seperti dijelaskan Sudidjono (1991:40): "Bila suatu penelitian bertujuan mendapatkan gambaran atau menemukan sesuatu sebagaimana adanya tentang sesuatu objek yang diteliti maka teknik analisis yang 
dibutuhkan cukup dengan perhitungan persentase".

Rumus yang digunakan untuk menghitung persentase adalah sebagai berikut:

$$
\mathrm{P}=\frac{\mathrm{F}}{\mathrm{N}} \times 100 \%
$$

Keterangan :

$\mathrm{P}=$ persentase

$\mathrm{F}=$ frekwensi responden (skor yang diperoleh)

$\mathrm{N}=$ jumlah responden

Tabel 3

Kategori nilai rata-rata

\begin{tabular}{|c|c|c|}
\hline No & $\begin{array}{c}\text { Persentase } \\
(\boldsymbol{\%})\end{array}$ & Klasifikasi \\
\hline 1 & $81-100$ & Baik sekali \\
\hline 2 & $61-80$ & Baik \\
\hline 3 & $41-60$ & Sedang \\
\hline 4 & $21-40$ & Kurang \\
\hline 5 & $0-20$ & Kurang sekali \\
\hline
\end{tabular}

Sumber: Ebel, R.L dan Frisbie,

DA. 1972. Essentials of

Education Measurement.

New York : Prentice

Hall

\section{HASIL DAN PEMBAHASAN}

Pada bab ini dilakukan analisis data tentang informasi yang diperoleh dari responden yakni secara berurutan dianalisis permasalahan yang dijumpai dalam penelitian ini secara berurutan mengenai Persepsi Siswa Terhadap Keterampilan Guru Dalam Pembelajaran Pendidikan Jasmani Olahraga dan Kesehatan di SDN 16 Pisang Kecamatan Pauh Kota Padang, antara lain:

\section{Membuka Pelajaran}

Data tentang Persepsi Siswa Terhadap Keterampilan Guru dalam Pembelajaran Pendidikan Jasmani Olahraga dan Kesehatan di SDN 16 Pisang Kecamatan Pauh Kota Padang, dengan variabel membuka pelajaran terdiri dari 44 orang siswa sebagai responden dan 8 item pernyataan.

Dan data dikelompokkan masing-masing jawaban berdasarkan nilai skor, dan data dihitung persentasenya, maka dapat dibuat rangkuman distribusi frekwensi Persepsi Siswa Terhadap Keterampilan Guru Dalam Pembelajaran Pendidikan Jasmani Olahraga dan Kesehatan di SDN 16 Pisang Kecamatan Pauh Kota Padang dengan variabel membuka pelajaran pada tabel berikut:

Tabel 4

Distribusi Frekwensi Membuka Pelajaran

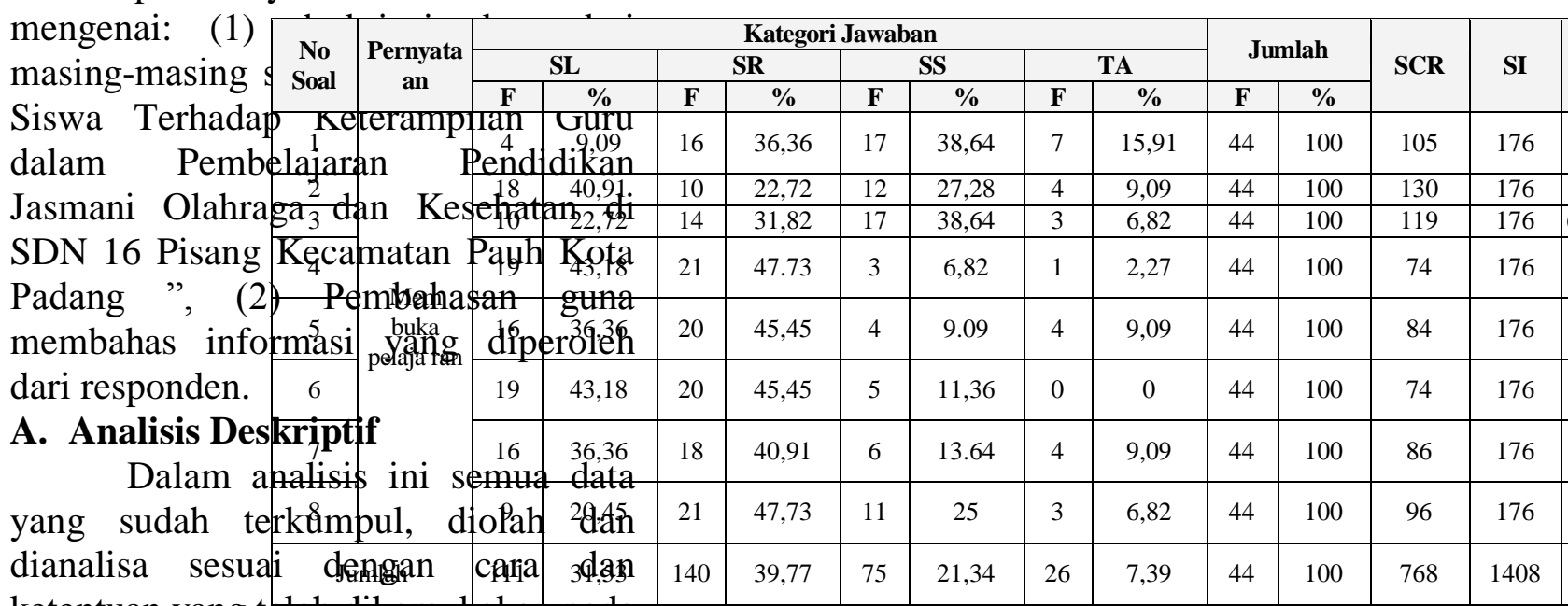
ketentuan yang telah dikemukakan pada bab yang terdahulu, berikut ini akan 
Dari tabel 4 di atas dapat dijelaskan bahwa 8 butir pernyataan 1- 8 yang dijawab responden sebanyak 44 orang, di mana masing-masing item terdiri dari 4 kategori, maka dapat diketahui sebanyak 111 kali dengan persentase $(31,53 \%)$ responden menjawab pernyataan dari variabel membuka pelajaran dengan selalu (SL) pada poin 4. Sebanyak 140 kali dengan persentase $(39,77 \%)$ responden menjawab pernyataan dari variabel membuka pelajaran dengan sering (SR) pada poin 3. Sebanyak 75 kali dengan persentase $(21,34 \%)$ responden menjawab pernyataan dari variabel membuka pelajaran dengan sekali-sekali (SS) pada poin 2. Sebanyak 26 orang dengan persentase $(7,39 \%)$ responden menjawab pernyataan dari variabel membuka pelajaran dengan tidak ada (TA) pada poin 1 . Rata-rata nilai skor tertinggi pada pernyataan dari variabel membuka pelajaran dalam kategori sering (SR) dengan jumlah persentase $(39,77 \%)$, dengan demikian dapat dikatakan bahwa membuka pelajaran penjasorkes termasuk dalam kategori "Kurang", yaitu jumlah jawaban responden

\begin{tabular}{|c|c|c|c|c|c|c|c|c|c|c|c|c|c|c|c|}
\hline sebanyak & & & & & & Katego & aw: & & & & & & & & \\
\hline Agar & $\begin{array}{c}\text { No } \\
\text { Soal }\end{array}$ & Pernyata & & $\mathbf{L}$ & & $\mathbf{R}$ & & $\overline{S S}$ & & $\mathbf{A}$ & & lah & SCR & SI & \\
\hline Mgar & & & $\mathbf{F}$ & $\%$ & $\mathbf{F}$ & $\%$ & $\mathbf{F}$ & $\%$ & $\mathbf{F}$ & $\%$ & $\mathbf{F}$ & $\%$ & & & \\
\hline digambar & Kagl C & tengan & Tमु & 2ब, ब95 & 8 & 18,18 & 15 & 34,09 & 8 & 18,18 & 44 & 100 & 114 & 176 & 6 \\
\hline gambar b & eriku & ini: & 11 & 25 & 12 & 27,27 & 21 & 47,73 & 0 & 0 & 44 & 100 & 98 & 176 & 5 \\
\hline & 11 & & 10 & 22,73 & 18 & 40,91 & 6 & 13,64 & 4 & 9,09 & 44 & 100 & 80 & 176 & 45 \\
\hline & 12 & laskan & 16 & 36,36 & 22 & 50 & 3 & 6,82 & 2 & 4,35 & 44 & 100 & 77 & 176 & 43 \\
\hline & 13 & & 17 & 38,64 & 3 & 6,82 & 10 & 22,73 & 13 & 29,55 & 44 & 100 & 110 & 176 & 6 \\
\hline & 14 & & 12 & 27,27 & 13 & 29,55 & 10 & 22,73 & 4 & 9,09 & 44 & 100 & 111 & 176 & 6 \\
\hline & 15 & & 12 & 27,27 & 18 & 40,91 & 9 & 20,45 & 5 & 11,36 & 44 & 100 & 125 & 176 & 7 \\
\hline
\end{tabular}

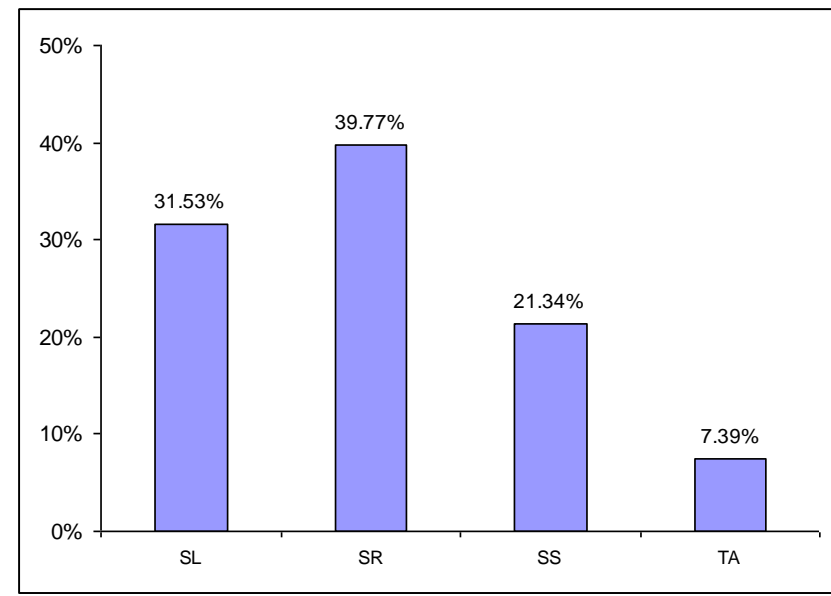

Gambar 2. Grafik Persepsi pada guru dalam membuka pelajaran

\section{Menjelaskan pelajaran}

Data tentang Persepsi Siswa Terhadap Keterampilan Guru Dalam Pembelajaran Pendidikan Jasmani Olahraga dan Kesehatan di SDN 16 Pisang Kecamatan Pauh Kota Padang, dengan variabel menjelaskan pelajaran terdiri dari 44 orang siswa sebagai responden dan 9 item pernyataan.

Data dikelompokkan masingmasing jawaban berdasarkan nilai skor, dan data di hitung persentasenya, maka dapat dibuat rangkuman distribusi frekwensi Persepsi Siswa Terhadap Keterampilan Guru Dalam Pembelajaran Pendidikan Jasmani Olahraga dan Kesehatan di SDN 16 Pisang Kecamatan Pauh Kota Padang dengan variabel menjelaskan pelajaran pada tabel berikut:

\section{Tabel 5}

Distribusi Frekwensi Menjelaskan Pelajaran 


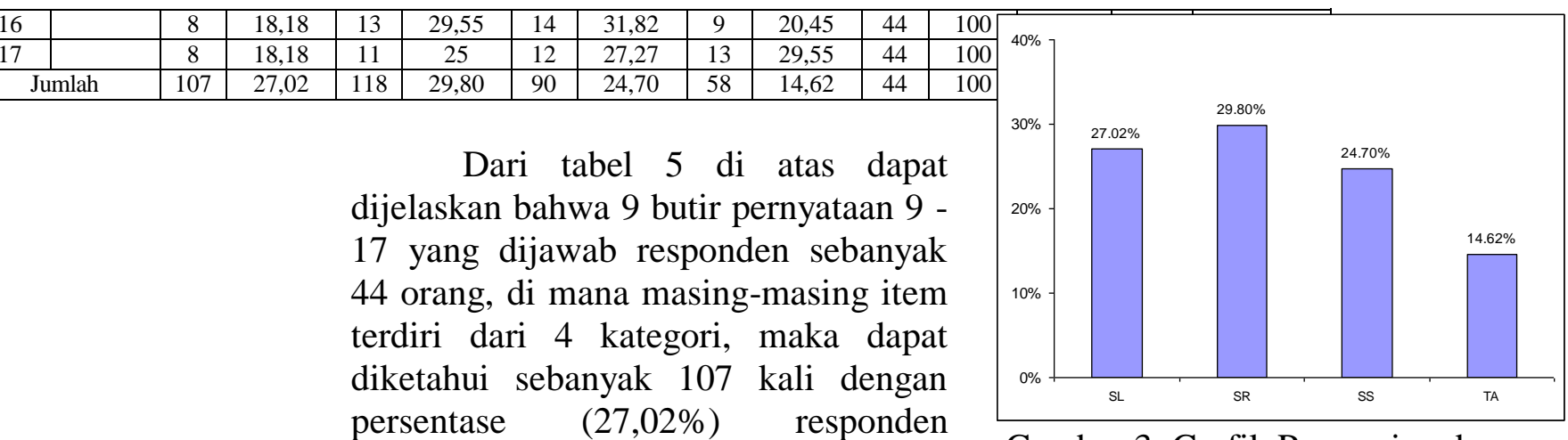
menjawab pernyataan dari variabel menjelaskan pelajaran dengan selalu (SL) pada poin 4. Sebanyak 118 kali dengan persentase $(29,80 \%)$ responden menjawab pernyataan dari variabel menjelaskan pelajaran dengan sering (SR) pada poin 3. Sebanyak 90 orang dengan persentase $(24,70 \%)$ responden menjawab pernyataan dari variabel menjelaskan pelajaran dengan sekalisekali (SS) pada poin 2.

Sebanyak 58 orang dengan persentase $(14,62 \%)$ responden menjawab pernyataan dari variabel menjelaskan pelajaran dengan tidak ada (TA) pada poin 1. Rata-rata nilai skor tertinggi pada pernyataan dari variabel menjelaskan pelajaran dalam kategori sering (SR) dengan jumlah persentase $(29,80 \%)$, dengan demikian dapat dikatakan bahwa menjelaskan pelajaran penjasorkes termasuk dalam kategori "kurang", yaitu jumlah jawaban responden sebanyak 118 kali $(29,80 \%)$.

Agar lebih jelasnya dapat digambarkan dengan grafik atau gambar berikut ini:

Gambar 3. Grafik Persepsi pada guru dalam menjelaskan pelajaran

\section{Mengelola kelas}

Data tentang Persepsi Siswa Terhadap Keterampilan Guru Dalam Pembelajaran Pendidikan Jasmani Olahraga dan Kesehatan di SDN 16 Pisang Kecamatan Pauh Kota Padang, dengan variabel mengelola kelas terdiri dari 44 orang siswa sebagai responden dan 10 item pernyataan.

Data dikelompokkan masingmasing jawaban berdasarkan nilai skor, dan data di hitung persentasenya, maka dapat dibuat rangkuman distribusi frekwensi Persepsi Siswa Terhadap Keterampilan Guru Dalam Pembelajaran Pendidikan Jasmani Olahraga dan Kesehatan di SDN 16 Pisang Kecamatan Pauh Kota Padang dengan variabel mengelola kelas pada tabel berikut :

Tabel 6

Distribusi Frekwensi Mengelola Kelas

\begin{tabular}{|c|c|c|c|c|c|c|c|c|c|}
\hline \multirow{3}{*}{$\begin{array}{l}\text { No } \\
\text { Soal }\end{array}$} & \multirow{3}{*}{$\begin{array}{c}\text { Pernyata } \\
\text { an }\end{array}$} & \multicolumn{8}{|c|}{ Kategori Jawaban } \\
\hline & & \multicolumn{2}{|c|}{ SL } & \multicolumn{2}{|c|}{ SR } & \multicolumn{2}{|c|}{ SS } & \multicolumn{2}{|c|}{ TA } \\
\hline & & $\mathbf{F}$ & $\%$ & $\mathbf{F}$ & $\%$ & $\mathbf{F}$ & $\%$ & $\mathbf{F}$ & $\%$ \\
\hline 18 & \multirow{8}{*}{$\begin{array}{c}\text { Mengelol } \\
\text { a kelas }\end{array}$} & 23 & 52,27 & 13 & 29,55 & 2 & 4,55 & 6 & 13,64 \\
\hline 19 & & 29 & 65,91 & 8 & 18,18 & 4 & 9.09 & 3 & 6,82 \\
\hline 20 & & 16 & 36,36 & 24 & 54,54 & 4 & 9,09 & 0 & 0 \\
\hline 21 & & 6 & 13,64 & 19 & 43,18 & 16 & 36,36 & 7 & 15,91 \\
\hline 22 & & 10 & 22,73 & 18 & 40,91 & 9 & 20,45 & 7 & 15,91 \\
\hline 23 & & 17 & 38,64 & 10 & 22,73 & 11 & 25 & 6 & 13,64 \\
\hline 24 & & 15 & 34,09 & 10 & 22,73 & 14 & 31,82 & 5 & 11,36 \\
\hline 25 & & 14 & 31,81 & 13 & 29,55 & 9 & 20,45 & 8 & 18,18 \\
\hline 26 & & 7 & 15,91 & 6 & 13,64 & 17 & 38,64 & 14 & 31,82 \\
\hline
\end{tabular}




\begin{tabular}{|c|c|c|c|c|c|c|c|}
\hline & & & & & & & \\
\hline 27 & & 19 & 43,18 & 10 & 22,73 & 8 & 18 \\
\hline \multicolumn{2}{|c|}{ Jumlah } & 156 & 35,45 & 131 & 29,77 & 94 & 21 \\
\hline
\end{tabular}

Dari tabel 6 diatas dapat dijelaskan bahwa 10 butir pernyataan 18 - 27 yang dijawab responden sebanyak 44 orang, di mana masingmasing item terdiri dari 4 kategori, maka dapat diketahui sebanyak 156 kali dengan persentase $(35,45 \%)$ responden menjawab pernyataan dari variabel mengelola kelas dengan selalu (SL) pada poin 4 , sebanyak 131 kali dengan persentase $(29,77 \%)$ responden menjawab pernyataan dari variabel mengelola kelas dengan sering (SR) pada poin 3, sebanyak 94 kali dengan persentase $(21,36 \%)$ responden menjawab pernyataan dari variabel mengelola kelas dengan sering (SS) pada poin 2, sebanyak 63 kali dengan persentase $(14,31 \%)$ responden menjawab pernyataan dari variabel mengelola kelas dengan tidak ada (TA) pada poin 1. Rata-rata nilai skor tertinggi pada pernyataan dari variabel mengelola kelas dalam kategori selalu (SL) dengan jumlah persentase $(35,45 \%)$, dengan demikian dapat dikatakan bahwa mengelola kelas penjasorkes termasuk dalam kategori "kurang", yaitu jumlah jawaban responden sebanyak 156 kali $(35,45 \%)$. Agar lebih jelasnya dapat digambarkan dengan grafik atau gambar 3 berikut ini:

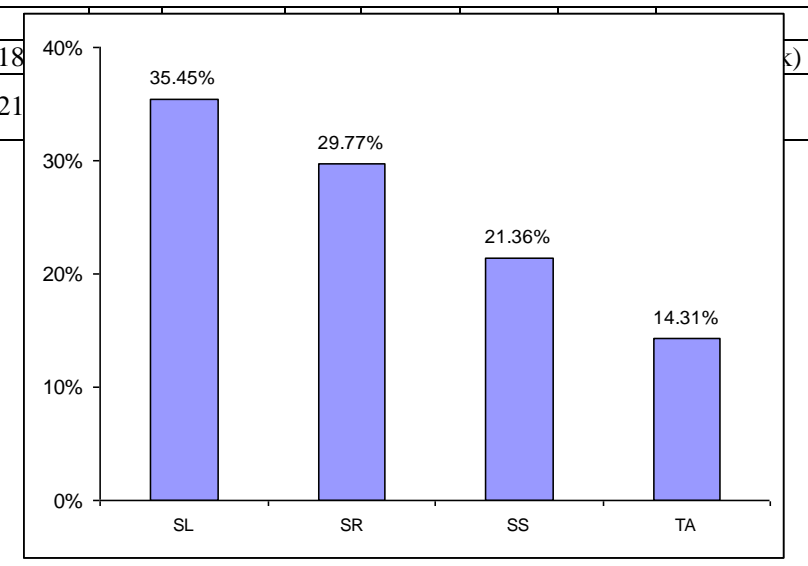

Gambar 4. Grafik Persepsi pada guru dalam mengelola kelas

\section{Menutup Pelajaran}

Data tentang Persepsi Siswa Terhadap Keterampilan Guru Dalam Pembelajaran Pendidikan Jasmani Olahraga dan Kesehatan di SDN 16 Pisang Kecamatan Pauh Kota Padang dengan variabel menutup pelajaran terdiri dari 44 orang siswa sebagai responden dan 3 item pernyataan.

Data dikelompokkan masingmasing jawaban berdasarkan nilai skor, dan data di hitung persentasenya, maka dapat dibuat rangkuman distribusi frekwensi Persepsi Siswa Terhadap Keterampilan Guru Dalam Pembelajaran Pendidikan Jasmani Olahraga dan Kesehatan di SDN 16 Pisang Kecamatan Pauh Kota Padang dengan variabel menutup pelajaran pada tabel 4 berikut :

Tabel 7

Distribusi Frekwensi Menutup Pelajaran

\begin{tabular}{|c|c|c|c|c|c|c|c|c|c|c|c|c|c|}
\hline \multirow{3}{*}{$\begin{array}{l}\text { No } \\
\text { Soal }\end{array}$} & \multirow{3}{*}{$\begin{array}{c}\text { Pernyata } \\
\text { an }\end{array}$} & \multicolumn{8}{|c|}{ Kategori Jawaban } & \multirow{2}{*}{\multicolumn{2}{|c|}{ Jumlah }} & \multirow{3}{*}{ SCR } & \multirow{3}{*}{ SI } \\
\hline & & \multicolumn{2}{|c|}{ SL } & \multicolumn{2}{|c|}{ SR } & \multicolumn{2}{|c|}{ SS } & \multicolumn{2}{|c|}{ TA } & & & & \\
\hline & & $\mathbf{F}$ & $\%$ & $\mathbf{F}$ & $\%$ & $\mathbf{F}$ & $\%$ & $\mathbf{F}$ & $\%$ & $\mathbf{F}$ & $\%$ & & \\
\hline 28 & \multirow{3}{*}{$\begin{array}{l}\text { Menu tup } \\
\text { pelaja ran }\end{array}$} & 13 & 29,55 & 13 & 29,55 & 11 & 6,25 & 7 & 15,91 & 44 & 100 & 100 & 176 \\
\hline 29 & & 7 & 15,91 & 17 & 38,64 & 9 & 20,45 & 4 & 2,27 & 44 & 100 & 101 & 176 \\
\hline 30 & & 5 & 11,36 & 9 & 20,45 & 8 & 18,18 & 12 & 27,27 & 44 & 100 & 75 & 176 \\
\hline \multicolumn{2}{|c|}{ Jumlah } & 25 & 18,94 & 39 & 29,55 & 28 & 14,96 & 25 & 15,15 & 44 & 100 & 276 & 528 \\
\hline
\end{tabular}


Dari tabel 7 di atas dapat dijelaskan bahwa 3 butir pernyataan 2830 yang dijawab responden sebanyak 44 orang, di mana masing-masing item terdiri dari 4 kategori, maka dapat diketahui sebanyak 25 kali dengan persentase $(18,94 \%)$ responden menjawab pernyataan dari variabel menutup pelajaran dengan selalu (SL) pada poin 4. Sebanyak 39 kali dengan persentase $(29,55 \%)$ responden menjawab pernyataan dari penggunaan variabel menutup pelajaran dengan sering pada poin 3 , sebanyak 28 kali dengan persentase $(14,96 \%)$ responden menjawab pernyataan dari variabel menutup pelajaran dengan sekali-sekali (SS) pada poin 2, sebanyak 25 kali dengan persentase $(15,15 \%)$ responden menjawab pernyataan dari variabel menutup pelajaran dengan tidak ada (TA) pada poin 1. Rata-rata nilai skor tertinggi pada pernysataan dari variabel menutup pelajaran dalam kategori sering (SR) dengan jumlah persentase $(29,55 \%)$, dengan demikian dapat dikatakan bahwa menutup pelajaran penjasorkes termasuk dalam kategori "kurang", yaitu jumlah jawaban responden sebanyak 39 kali $(29,55 \%)$. Agar lebih jelasnya dapat digambarkan dengan grafik atau gambar 4 berikut ini:

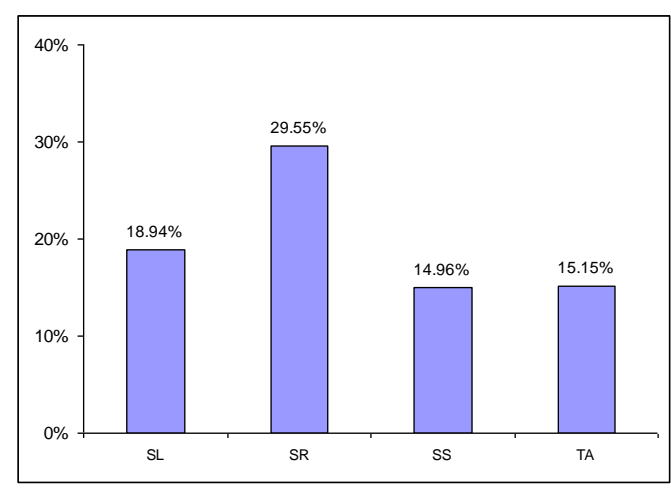

Gambar 5. Grafik Persepsi pada guru dalam menutup pelajaran

\section{Pembahasan}

Dari data yang diperoleh pada analisis deskriptif, terdapat beberapa hal indikator-indikator yang berpengaruh pada "Persepsi Siswa Terhadap Keterampilan Guru Dalam Pembelajaran Pendidikan Jasmani Olahraga dan Kesehatan di SDN 16 Pisang Kecamatan Pauh Kota Padang". Oleh karena itu perlu adanya pembahasan indikator-indikator tersebut yang akan dijelaskan satu persatu dengan yang ada, sebagai berikut:

Dalam proses belajar mengajar pendidikan jasmani dan kesehatan keterampilan membuka pelajaran merupakan salah satu faktor penting yang harus dikuasai guru. Sebab dengan adanya keterampilan membuka pelajaran akan dapat lebih mengarahkan siswa kepada pelaksanaan pembelajaran berikutnya, terlebih lagi peiaksanaan pengajaran dilakukan di lapangan yang mana banyak faktor mengganggu perhatian siswa.

Agar pelajaran pendidikan jasmani olahraga dan kesehatan tetap pada suasana yang dinamis, guru perlu merumuskan dengan jelas tujuan apa yang ingin dicapainya dan hal ini dicerminkan dalam metode membuka pelajaran.

Tujuan akhir dari pendidikan jasmani adalah gerakan atau keterampilan yang memiliki siswa melalui proses kegiatan aktifitas manusia. Psikomotor merupakan tujuan utama dalam pembelajaran pendidikan jasmani. Oleh sebab itu, guru sebagai seseorang yang memiliki potensi dan kemampuan membuka pelajaran, dituntut untuk mampu melaksanakan pembelajaran yang meliputi persiapan alat, mengambil absen, memimpin 
stretching, memberikan permainan kecil, ringkasan teori yang diajarkan, pemberian informasi langkah-langkah tentang apa yang akan dilakukan siswa, pengajuan pertanyaan dan mereview materi minggu lalu.

Untuk meningkatkan efektif proses pembelajaran, guru harus dapat menjelaskan pelajaran dengan baik, agar tujuan pembelajaran dapat tercapai dengan baik. Apabila guru dapat menjelaskan pelajaran dengan baik, maka materi pelajaran yang dibutuhkan untuk kegiatan siswa akan dapat terlaksana dengan baik.

Agar bahan pelajaran dapat disajikan dalam kegiatan siswa, guru harus mampu menjelaskan pelajaran yang dibuat sebelumnya, sehingga siswa memahami kegiatan yang akan dilakukan untuk mencapai tujuan pembelajaran. Tiap guru harus mampu menjelaskan pelajaran sebelum ia dengan penuh tanggung jawab dapat memasuki kelas, sebab mengajar merupakan tugas yang begitu kompleks dan sulit, sehingga tidak dapat dilakukan dengan baik oleh siapa pun tanpa persiapan untuk menjelaskan pelajaran.

Dalam pembelajaran proses belajar mengajar guru dituntut mencapai tujuan pengajaran dengan sebaik-baiknya. Untuk mendorong keberhasilan pengajaran hal penting untuk diketahui oleh guru adalah metode apa yang cocok digunakan untuk mengelola kelas dengan baik.

Jadi, mengelola kelas dirancang sesuai dengan tujuan yang ingin dicapai dan dapat mendorong siswa untuk beraktivitas sesuai dengan gaya belajarnya. Oleh sebab itu, guru sebagai seseorang yang memiliki potensi dan kemampuan dalam pembelajaran, dituntut untuk mampu mengelola kelas dengan sebaik mungkin agar tujuan pembelajaran dapat tercapai secara efektif dan efesien, seperti; membagi perhatian, mengatur posisi atau tempat, memberi petunjuk.

Keterampilan menutup peiajaran adalah kegiatan yang dilakukan guru untuk mengakhiri pelajaran atau kegiatan pembelajaran dengan mengemukakan kembali pokokpokok pelajaran yang berfungsi untuk memberikan gambaran menyeluruh tentang apa yang telah dipelajari dan mengetahui keberhasilan siswa dalam menyerap pelajaran dan menentukan titik pangkal untuk pelajaran berikutnya. Salah satu usaha yang dapat dilakukan oleh guru sebelum menutup pelajaran adalah dengan melakukan evaluasi.

Evaluasi atau suatu penilaian merupakan tugas lanjutan guru untuk menilai apakah tujuan, kemajuan dalam menerima pelajaran dan hasil belajar di kelas telah tercapai oleh siswa. Penilaian yang dilakukan guru penjasorkes dilihat dengan menguji siswa dalam melaksanakan gerakangerakan yang telah dipelajarinya dan bagaimana siswa mengembangkan gerakan tersebut dan hal ini dilakukan pada saat menutup pelajaran.

\begin{tabular}{llr}
\multicolumn{1}{c}{ Penilaian diambil } & dengan \\
menggunakan & laporan & hasil \\
pengamatan guru disetiap akhir
\end{tabular}
pelajaran. Dengan adanya lembar pengamatan tersebut memudahkan guru dalam memberikan penilaian yang objektif karena pengamatan tersebut dan nilai yang diperoleh siswa dapat dijadikan sebagai patokan keberhasilan siswa. Oleh sebab itu penting kiranya suatu proses pembelajaran pendidikan jasmani dilakukan evaluasi sebelum menutup pelajaran. 


\section{Kesimpulan}

Berdasarkan hasil penelitian tentang "Persepsi Siswa Terhadap Keterampilan Guru Dalam Pembelajaran Pendidikan Jasmani Olahraga dan Kesehatan di SDN 16 Pisang Kecamatan Pauh Kota Padang". Maka dapat disimpulkan :

1. Dari hasil analisis data dan deskripsi hasil penelitian tentang Persepsi Siswa Terhadap Keterampilan Guru Dalam Pembelajaran Pendidikan Jasmani Olahraga dan Kesehatan di SDN 16 Pisang Kecamatan Pauh Kota Padang dengan sub variabel membuka pembelajaran diklasifikasikan "Cukup" dengan perolehan persentase $(55,54 \%)$.

2. Dari hasil analisis data dan deskripsi hasil penelitian tentang Persepsi Siswa Terhadap Keterampilan Guru Dalam Pembelajaran Pendidikan Jasmani Olahraga dan Kesehatan di SDN 16 Pisang Kecamatan Pauh Kota Padang dengan sub variabel materi pembelajaran diklasifikasikan "Cukup" yaitu dengan perolehan persentase $(58,40 \%)$.

3. Dari hasil analisis data dan deskripsi hasil penelitian tentang Persepsi Siswa Terhadap Keterampilan Guru Dalam Pembelajaran Pendidikan Jasmani Olahraga dan Kesehatan di SDN 16 Pisang Kecamatan Pauh Kota Padang dengan sub variabel metode pembelajaran diklasifikasikan "Cukup" yaitu dengan perolehan persentase $(58,98 \%)$.

4. Dari hasil analisis data dan deskripsi hasil penelitian tentang Persepsi Siswa Terhadap Keterampilan Guru Dalam Pembelajaran Pendidikan Jasmani
Olahraga dan Kesehatan di SDN 16 Pisang Kecamatan Pauh Kota Padang dengan sub variabel media/alat pembelajaran diklasifikasikan "Cukup" yaitu dengan perolehan persentase $(52,27 \%)$.

Berdasarkan kesimpulan di atas, penulis menyarankan agar:

1. Disarankan pada siswa dapat menyadari pentingnya proses pembelajaran pendidikan jasmani olahraga dan kesehatan bagi tercapainya tujuan pembelajaran.

2. Disarankan kepada guru pendidikan jasmani olahraga dan kesehatan dapat menjalankan proses pembelajaran dengan memilih metode yang tepat baik dari segi membuka pelajaran, menjelaskan pelajaran, mengelola kelas dan menutup pelajaran agar tercapainya tujuan pembelajaran secara efektif dan efesien.

3. Penelitian ini hanya terbatas pada Persepsi Siswa Terhadap Keterampilan Guru Dalam Pembelajaran Pendidikan Jasmani Olahraga dan Kesehatan di SDN 16 Pisang Kecamatan Pauh Kota Padang, oleh sebab itu bagi peneliti selanjutnya hal ini dapat dijadikan sebagai sumber informasi dalam pengembangan penelitian selanjutnya dengan jumlah populasi yang lebih besar dan di daerah yang berbeda.

\section{DAFTAR PUSTAKA}

Daniel, Nurafdi. 2008. Hubungan Minat dengan Tingkat Kesegaran Jasmani terhadap Hasil Belajar Penjasorkes Siswa Putir di SMA 
PGRI Kota Sawahlunto. Padang: FIK UNP.

Effendi, Mawardi. 2010. Istilah-Istilah dalam Peraktek Mengajar dan Pembelajaran. Padang: UNP Press.

Gusti Regina, Monica. 2012. Pengaruh Metode Pembelajaran Kooperatif Tipe Tink-Pair-Share Untuk Meningkatkan Minat Belajar Siswa. Teknik Elektronika. FT UNP.

Hamzah. 2012. Teori Motivasi dan Pengukurannya Analisis di Bidang Pendidikan. Jakarta: Bumi Aksara.

Kharanis dan Darnis Arif. 2000. Perkembangan Dan Belajar Peserta Didik. UNP.

Majid, Abdul. 2012. Perencanaan Pembelajaran Mengembangkan Standar Guru. Bandung: Remaja Rosdakarya.

Muslich, Masnur. 2010. Bagaimana menulis sikripsi?. Jakarta: Bumi Askara.

Patusari, Achmad. 2012. Manejemen Pendidikan Jasmani dan olahraga. Jakarta: PT. Rineka Cipta.

Rosdiani, Dini. 2012. Dinamika Olahraga dan Pengembangan Nilai. Bandung: Alfabeta.

Sardiman. 2001. Interaksi dan Motivasi Belajar Mengajar. Jakarta: PT Raja Grafido Persada.

Warlina, Reni. 2008. Upaya Meningkatkan Minat Membaca Anak melalui Permainan Kotak
Pintar di TK Aisyiyah Suliki Kabupaten Lima Puluh Kota. FIP UNP. 